\title{
Cultivating Powerful Participation: Reflections from a food justice and facilitation learning experience
}

\author{
Jamie Bain, ${ }^{a *}$ Noelle Harden, ${ }^{\mathrm{b}}$ Shirley Nordrum, ${ }^{\mathrm{c}}$ and Ren Olive ${ }^{\mathrm{d}}$ \\ University of Minnesota Extension
}

Submitted February 26, 2021 / Revised June 16 and August 17, 2021 / Accepted August 18, 2021 /

Published online December 16, 2021

Citation: Bain, J., Harden, N., Nordrum, S., \& Olive, R. (2021). Cultivating Powerful Participation:

Reflections from a food justice and facilitation learning experience. Journal of Agriculture, Food

Systems, and Community Development, 11(1), 59-80. https://doi.org/10.5304/jafscd.2021.111.014

Copyright (C) 2021 by the Authors. Published by the Lyson Center for Civic Agriculture and Food Systems. Open access under CC-BY license.

\begin{abstract}
In the aftermath of the COVID-19 pandemic and heightened awareness of systemic racism this past year, food systems practitioners are increasingly turning their attention toward the intersections of racial equity and the good food movement. Unpacking the racist history of the food system is a key step in this journey toward food justice, one
\end{abstract}

a* Corresponding author: Jamie Bain, MPH, Extension Educator, Center for Family Development, University of Minnesota Extension; (permanent address) 2001 Plymouth Avenue N; Minneapolis, MN 55411 USA; +1-612-239-5571; ibain@umn.edu

b Noelle Harden, MSA, Extension Educator, Center for Family Development, University of Minnesota Extension; harde073@umn.edu

c Shirley Nordrum, Extension Educator, Center for Agriculture, Food, and Natural Resources, University of Minnesota Extension; nordr006@umn.edu

d Ren Olive, Program Associate, University of Minnesota Extension, Regional Sustainable Development Partnerships; rolive@,umn.edu that must be followed by intentional action bridging diverse perspectives through skilled facilitation. Through a project called Cultivating Powerful Participation, the University of Minnesota Extension and food justice practitioners across Minnesota are working together to equip leaders with the necessary relationships, skills, and tools to cultivate a vision of food justice. In this reflective essay, we draw on our experiences leading this initiative to demonstrate the power and impact of approaching food justice through an action-oriented framework that equips community food justice leaders to become seasoned facilitators. Using themes and evaluation data from our program, we share promising practices and specific facilitation methods that others can adapt to embrace a justice orientation in their work.

\footnotetext{
Funding Disclosure

Funding for this work came from the Supplemental Nutrition Assistance Program Education (SNAP-Ed) and Minnesota Food Charter Network led by the University of Minnesota Institute for Healthy Foods and Healthy Lives.
} 


\section{Keywords}

Food Justice, Pedagogy, Racial Equity, Engagement, Facilitation

\section{Introduction}

Eric Holt-Giménez (2015) notes that "understanding why, where, and how racism manifests itself in the food system, recognizing it within our movement and our organizations and within ourselves, is not extra work in transforming the food system, it is the work" (p. 24). From the massive dispossession of land and foods of the Native Americans to the enslavement and trading of Africans to jumpstart the European-style agricultural system in the United States, we know that the U.S. food system was founded and built upon a system of racism perpetrated at the hands of White colonizers (Holt-Giménez \& Harper, 2016). We also know the modern U.S. agricultural system, and the organizations like Extension that uphold that system, continue to prevent Black, Indigenous, and People of Color (BIPOC) from having the same advantages as White people (Lee \& Ahtone, 2020; Montenegro de Wit, 2020). This dynamic is clearly illustrated by the disparities in diet-related diseases, access to affordable, healthy, and local foods, and, most recently, COVID-19 rates, to name a few (Nittle, 2021).

Yet, at this time of extreme polarization in the U.S., evidenced by the authors' lived experience working to advance more equitable food systems, some practitioners still refuse to acknowledge that racism is an issue within the food system (e.g., Heeb, 2021). In addition, the authors have observed that others understand the impacts of racism on the food system in purely intellectual ways and struggle to see how it affects their daily actions and decisions. And there are still others who understand and see themselves perpetuating racist actions but don't feel like they have the tools or relationships to do things differently.

All of this means that we need food system practitioners to understand the pernicious effects of racism within themselves, their communities, and their organizations. Cadieux and Slocum (2015) explain that creating a just food system requires us to not only have honest conversations about racism and trauma but also to redesign how food is exchanged, to reconceive land-use practices and ownership, and to pay people a living wage. Furthermore, these authors and others argue that food justice cannot be accomplished in isolation from other sectors such as economic, carceral, and environmental justice (Sbicca, 2018). Thus, food system practitioners also need the skills and relationships to design and implement novel, complex, and collaborative solutions.

Through a project called Cultivating Powerful Participation: Food Justice Facilitation Workshops (CPP), the University of Minnesota (UMN) Extension Center for Family Development (Extension) and food system practitioners across Minnesota worked together to equip leaders with the necessary skills, relationships, and tools to cultivate a vision of food justice (UMN Extension, 2020). This essay reflects on the first two years of this effort, sharing resources we developed and key considerations for CPP facilitators and other food justice educators who may leverage our experiences and materials in their programs.

\section{Food Justice Pedagogy: Lessons from the Literature}

Food justice is a growing field with substantial literature pointing to different aspects of its meaning, how it works, and where it's being done. We share two definitions of food justice in the literature that we found particularly useful to ground this paper in common language and understanding of the term. However, the CPP train-the-trainer (TTT) cohort (see Overview of Cultivating Powerful Participation section below for a detailed discussion of this cohort) argued that the term should not be defined because it is as ever-changing and nuanced as communities and practitioners. They warn that defining a term like food justice is falling into the White Supremacy Culture trap of "Worship of the Written Word" because it imposes a one-size-fits-all understanding of concepts that communities should define (Okun, 1999).

Although food justice theory and practice are growing fields in the literature, there is less regarding food justice pedagogy. Valley et al. (2020) conducted a scan of sustainable food systems education (SFSE) models and determined that $80 \%$ do not contain an explicit equity lens. They call for 
scholars to do more work in the field of food justice pedagogy and ask practitioners to consider making their work more explicitly anti-racist by adopting their equity competency model. The model builds on four domains: awareness of self, awareness of others and one's interactions with them, awareness of systems of oppression, and strategies and tactics for dismantling inequities.

The go-to pedagogical approach identified in the literature appears to be service-learning. Kaiser et al. (2015) provide an overview of various pedagogical approaches for teaching food justice to social work students, including service-learning, classroom resources, and discussions, as well as a "food insecurity simulation" activity. Aftandilian and Dart (2013) go deeper into the service-learning approach by providing best practices for gardenbased service learning from three projects that took place in Fort Worth. Another article focused on the service-learning approach discusses how volunteers built "strong civic virtues and critical perspectives" by participating in urban agriculture programs in Canadian community food centers (Levkoe, 2006, p. 90). Although service-learning is a model widely used in higher education, some question its effectiveness as a tool for teaching social justice. They critique its potential to extract learning from minority communities rather than provide authentic support to important causes (Butin, 2007).

There are a few models in the literature that go beyond service-learning. Neiman and Schroedel (2019) discuss their four pedagogical themes for students in an alternative learning setting, including (1) an introspective understand- ing of racism, (2) democratizing the classroom, (3) building trusting relationships, and (4) leveraging social capital into political capital. Brown et al. (2020) share their immersive learning experience called "The History of the Land" that they lead at Grow Dat Youth Farm in New Orleans. Brown and colleagues show how offering youth the opportunity to connect with the land fosters food justice values. The workshop includes small group activities, a walking tour, and conversations that explore the history of oppression tied to a particular piece of land in New Orleans. The workshop concludes by imagining how the land could be used in the future, and a conversation connecting how what they've learned could impact their daily choices and experiences. Thus, the authors argue, "while learning the history of the land is essential to understanding the spatial and social configurations of contemporary foodscapes, the result is a point of departure rather than an end, a beginning from which to envision alternate futures of radical food geographies" (p. 250).

In this reflective essay, we seek to add a novel pedagogical approach to food justice to the literature. We show how the program builds off core tenets-relationship development, participatory processes, and action-orientation-in the literature. We also share the ideas that make this program unique, such as focusing on practitioner participation (rather than students), centering community voices in all stages of the program, creating warm and welcoming learning environments, and anchoring facilitation skills in topics participants are passionate about-food justice. Our hope is for readers to apply or adapt the offerings shared in this

\section{Food Justice Definitions in the Literature}

"We characterize food justice as ensuring that the benefits and risks of where, what, and how food is grown and produced, transported and distributed, and accessed and eaten are shared fairly." (Gottlieb \& Joshi, 2010, p. 6)

"Food justice is the right of communities everywhere to produce, process, distribute, access, and eat good food regardless of race, class, gender, ethnicity, citizenship, ability, religion, or community. Includes:

- Freedom from exploitation

- $\quad$ Ensures the rights of workers to fair labor practices

- Values-based: respect, empathy, pluralism, valuing knowledge

- $\quad$ Racial Justice: dismantling of racism and white privilege

- Gender equity"

(Institute for Agriculture and Trade Policy [IATP], 2012, para. 7) 
article or take away lessons to improve their pedagogical approach to food justice.

\section{Overview of Cultivating Powerful Participation}

The first round of the CPP program was launched in August 2019 by the University of Minnesota Extension Center for Family Development (Extension). The purpose of this version of CPP was to support Supplemental Nutrition Assistance Education (SNAP-Ed) staff to facilitate food justice work in their communities. The program's overall structure was designed and coordinated by three Extension staff (two of whom are authors of this article) partially funded by SNAP-Ed. The coordinators identify as cis-gendered, heterosexual, White women. These coordinators have taken several facilitation training sessions. Together they bring many years of experience in facilitating and delivering highly participatory, community-driven, food justice programs across MINNESOTA. These skills were used to design the original CPP pro- gram, which took place in two phases (outlined further in the following subsections and Figure 1). In phase one, a diverse group of SNAP-Ed staff and community and organizational partners participated in a unique train-the-trainer (TTT) cohort program. In phase two, the participants of the T'T'T cohort broke up into smaller facilitation teams to lead eight regional workshops across the state with other SNAP-Ed staff and community and organizational partners.

\section{Phase 1. Train-the-Trainer}

The first phase was designed similarly to a typical train-the-trainer (T'T'T) program (Cserti, 2020). A group of participants is trained on how to implement a program or curriculum, in this case, to facilitate food justice facilitation workshops in their communities. However, the goal for CPP was for participants to gain skills as facilitators and apply them to co-create the workshops they would later offer to their communities. This model was chosen to (1) provide a deep learning and networking

\section{Figure 1. Cultivating Powerful Participation: Food Justice Facilitation Workshops (CPP) Roles and Responsibilities}

\begin{tabular}{|c|c|c|}
\hline $\begin{array}{l}\text { Coordinators } \\
\text { Design overall structure }\end{array}$ & \multicolumn{2}{|c|}{ Phase 1: Train-the-Trainer (TT) Members } \\
\hline \multirow{2}{*}{$\begin{array}{l}\text { Recruit TTT cohort selection } \\
\text { committee members }\end{array}$} & \multirow{2}{*}{$\begin{array}{l}\text { Apply for TTT cohort (includes } \\
\text { SNAP-Ed Educators, community } \\
\text { partners, and organizational } \\
\text { partners) }\end{array}$} & Phase 2: Workshop Participants \\
\hline & & $\begin{array}{l}\text { Register and attendatwo-day, } \\
\text { free, regional workshop }\end{array}$ \\
\hline $\begin{array}{l}\text { Facilitate TTT cohort selection } \\
\text { committee decision making } \\
\text { process }\end{array}$ & $\begin{array}{l}\text { Participate in four-day TTT } \\
\text { training }\end{array}$ & $\begin{array}{l}\text { Complete an evaluation of } \\
\text { workshop experience }\end{array}$ \\
\hline $\begin{array}{l}\text { Hire and work alongside TTT } \\
\text { cohort trainers }\end{array}$ & $\begin{array}{l}\text { Identify one-to two other TTT } \\
\text { cohort members to work with to } \\
\text { create a faciltiation team }\end{array}$ & \\
\hline Coach facilitation teams & Serve on a facilitation team to & \\
\hline $\begin{array}{l}\text { Work with facilitation teams to } \\
\text { co-design, deliver, and evaluate } \\
\text { the workshops }\end{array}$ & $\begin{array}{l}\text { receive coaching and to co-design, } \\
\text { deliver, and evaluate a workshop } \\
\text { Complete an evaluation of TTT } \\
\text { experience }\end{array}$ & \\
\hline
\end{tabular}


experience to a cohort of passionate food justice leaders across Minnesota, (2) to co-create workshop agendas with participants who are representative of the diversity of needs in areas of the state with the greatest food injustice, (3) to create a sense of identity and belonging at the workshops by identifying facilitators who represent the communities served, an d (4) to invest in community partners that Extension wanted to work more closely with to advance food justice efforts across Minnesota.

The coordinators developed an application process to recruit the TT'T cohort, targeting half community partners and half SNAP-Ed staff. The application for the TTT cohort was disseminated through food-focused and Extension listservs along with personal emails sent to grassroots food system leaders and SNAP-Ed staff. Altogether, there were 22 applicants from organizational and community partners and 10 from within SNAPEd. Organizational and community partners were offered US $\$ 45 /$ hour for their time spent learning together and designing, implementing, and debriefing the experience. SNAP-Ed staff was not compensated financially beyond their salary, but they were provided relief from some of their other obligations to focus more fully on this professional development opportunity.

To eliminate bias in the selection process as much as possible, the coordinators recruited a diverse selection committee to choose cohort participants. The committee members were recruited from within Extension and from social justice leaders the coordinators had relationships with in the community. Each selection committee member reviewed and scored each application using a common scoring rubric, which included scoring for applicants' level of experience with both facilitation and food system work, what attracted them to the program, and their professional and lived experience working on social justice. All selection committee members were provided with a short training on how to use the rubric.

Using the rubric scores and consideration for racial and geographic diversity, the coordinators facilitated a consensus-building process to support the selection committee in determining T'T'T cohort participants. In the end, the committee selected seven candidates from organizational and community partners and seven from within SNAPEd, creating a TT'T cohort of 14 participants. The cohort was diverse in a variety of ways, including $65 \%$ BIPOC representation. In addition, two of the cohort participants are also authors of this essay who work in different Extension centers than the coordinators; one identifies as Anishinaabe Ikwe (an Ojibwe woman) and the other as a White non-binary transgender person.

The coordinators hired three racially diverse facilitation experts to lead the T'T'T cohort through a four-day training in the Fall of 2019. The coordinators worked alongside the trainers to focus on food justice while also participating in the training. Each day included activities where participants learned about a facilitation method and then experienced that method through a lens of food justice. Each activity concluded with a facilitated discussion to help participants apply and teach others the method in their work and community (practices are described in greater depth in the CPP in Action section).

At the end of the four-day TT'T cohort training, participants self-organized into facilitation teams of two to three participants and one coordinator based on identities, interest, and geographic representation, for a total of eight teams. Each facilitation team designed and implemented one workshop in their geographic region of the state for a total of eight workshops. During workshop planning, the coordinators served as coaches and organizers of the facilitation teams. Coordinators coached the small teams for anywhere from four to 20 hours, depending on their needs. The facilitation teams shared their agendas and insights over email and shared documents, so they could learn from each other as the planning and implementation of the workshops unfolded (see Appendix A for an example workshop agenda).

\section{Phase 2. Workshops}

During the second phase of CPP, facilitation teams lead free two-day workshops for participants to learn and practice how to facilitate food justice work in their communities. The purpose of the workshops was to help participants: (1) engage across differences (e.g., race, geography, sector), (2) 
build a diverse network of relationships, (3) gain a greater understanding of food justice through interactive and engaging facilitated conversations, and (4) advance participants' ability to do food justice work by using equity-based facilitation practices.

The two-day workshops took place from November 2019-February 2020. The workshops were offered at no cost and marketed broadly using the same mechanisms as the TTT cohort applications, with a target audience of food systems practitioners interested in advancing food justice. The facilitation teams also encouraged participation through local marketing in their communities. On average, 25 participants attended each of the workshops, with 214 total participants.

The average workshop participant demographic breakdown included about 30\% community partners (food system practitioners not associated with an organization), $40 \%$ organizational partners, and 30\% SNAP-Ed staff. The racial diversity of participants varied by location due to the demographics of Minnesota. For instance, all the metro workshops had about 50\% BIPOC participation, whereas most workshops in rural Minnesota had about $20 \%$ BIPOC participation. One workshop took place at an Indigenous community center in rural Minnesota and included almost $100 \%$ Indigenous community participation. The workshops had the same general format as the TTT cohort training. Participants learned about facilitation methods, then experienced the method with a food justice lens, and concluded with a discussion about the value and utility of the method in advancing food justice in their communities.

\section{CPP in Action}

Now that we've described the overall structure and framework for CPP, let's examine what the program looked like in practice. Both the TT'T cohort training and workshops included various activities: icebreakers, active breaks, time for silent reflection, conversations on what it means to be a facilitator, and other creative activities. In this section, we share a variety of practices drawn from the authors' personal experiences that we believe were critical to the program's success. See Appendix A for a more detailed look at a workshop agenda.

\section{Practice \#1: Sequence Questions to Guide Deeper Reflections}

The facilitation method of Focused Conversation or ORID (an acronym for Objective, Reflective, Interpretive, and Decisional) was taught at the TT'T cohort training and workshops to help participants gain a deeper understanding of food justice (ICA International, 2015). The ORID method sequences questions in a way that uses the body's natural way of processing information to induce participants toward greater critical thinking. To get workshop participants on the same page about the food injustices prevalent in Minnesota and how food justice and facilitation are connected, the three metro facilitation teams used ORID to start each workshop. They first had participants form small breakout groups of five to six people, read a list of food injustice data relevant to Minnesota, then discuss their reactions using the following sequence of questions:

- "What stuck out to you when you read these food injustice facts?" (Objective)

- "What was your gut reaction to these facts?" (Reflective)

- "What would a just food system look like to you?" (Interpretive)

- "How could we use the skills we're learning in this workshop to advance this vision of food justice?" (Decisional)

Each time this method was taught, trainers and facilitators helped participants see how meetings are often structured to ask participants to make decisions without supporting their ability to process information effectively before making these decisions. Participants reflected how more comprehensive and creative decision-making processes could be if this method were used more often. Informant feedback from workshop participants has consistently pointed to ORID as valuable because of its wide applicability and ease of use to create deeper engagement in meetings.

\section{Practice \#2: Hone Listening as a Critical Skill}

Another facilitation method taught in both the T'T'T cohort training and the workshops is the 
Reflective Listening Technique developed by The Compassionate Listening Project (2013, p.6). In this method, participants split into groups of four people and rotate roles between storyteller, listener for facts, listener for feelings, and listener for values. The storyteller responds to a deeply introspective prompt, such as "Share a story of a time when you acted with courage in your food justice work," while the others listen deeply for a different aspect (facts, feelings, values). Afterward, the listeners reflect on what they heard from the storyteller. Each time this method was done, participants noted how valuable it was to feel seen and heard in the storyteller role and to understand how to listen more wholeheartedly. Each time, the trainers and facilitators helped to highlight that to advance food justice, we need to listen fully to community needs, people who see things differently than us, and each other.

\section{Practice \#3: Use Cues to Support Experiential Learning}

The TT'T cohort training and workshops addressed topics like oppression, land access, racism, and cultural appropriation through a deeply personal and introspective approach by using cues and questions. Cues were most often used to differentiate between "learner" and "participant" modes. The facilitators made sure participants knew they were in "learner mode" as they were first taught a facilitation method (i.e., how the method works, when to use it, when not to use it, how many people to use it with, and the average length of the experience). Then the facilitators provided cues to the participants, so they knew they were entering into "participant mode" as they engaged in the method with a lens of food justice (similar to what was described in Practice \#1 and \#2) and debriefed what they had learned from their experience. Then facilitators provided cues for them to come back to "learner mode" to debrief their experience with the method and think about how they could apply it to their food justice work.

\section{Practice \#4: Lean on Shared Agreements in Times of Tension}

The TTT cohort training began with co-creating shared agreements or guidelines for how partici- pants wanted to engage with one another. For example, one agreement was to "stay in relationship with each other even when it gets hard." This agreement was critical for the group to self-manage tension that surfaced when learning the "fishbowl" method. In this activity, three to six people sit in an inner circle and dialogue about a topic while a larger group of participants sits around the circle and listen. All participants can move in and out of the inner circle, and there is always one spot open for someone to join the inner circle (McCandless, n.d.-b).

The Fishbowl activity took place on the third day of the TTT cohort training when the group was ready to dig into tough topics related to food justice. The focus of the activity was on power, and the conversation evolved to cover a range of topics from spiritual oppression to land access to the concept of colorism. The conversation became quite emotionally charged at one point, so the trainers chose to pause the conversation and give everyone a break. The trainers reconvened the participants with a reminder of the shared agreements they had co-created at the beginning of their time together. The resulting sense of group accountability enabled the cohort to work through a difficult moment and stay in a relationship with each other. As a result of this experience, every facilitation team designed their workshop agendas to begin with the co-creation of shared agreements and consistently referenced the agreements throughout the workshops when necessary.

\section{Practice \#5: Tend to Comfort and Belonging} The authors identified (through evaluation data and personal experience) a list of small but important details they believed helped create a welcoming and safe space for workshop participants to learn, be vulnerable, and dig deep into their experiences. These details started before the workshops even began; for example, facilitation teams carefully selected locations and food vendors, considering the cultural context of participants. Workshops were often held in community centers accessible by bus. All workshop locations were also chosen to have enough unobstructed wall space to hang posters and art murals and share notes on large sticky paper. The food vendors were sourced from small 
BIPOC-owned establishments. Additionally, each facilitation team sent a "welcome letter" to participants to prepare them for what to expect in the workshops and help them feel ready and grounded.

Other details that supported a welcoming learning environment were in how the space was set up. Every workshop included a resource table with a "hospitality kit," which included tissues, cough drops, and headache medication, as well as healthy snacks, water, coffee, and a supply of books the facilitators recommended. All workshop tables included fidget toys, art supplies, paper for taking notes or doodling, and a centerpiece. Each facilitation team created a playlist specific for their workshop and played music during breaks and reflection times. Lastly, all workshop participants received a binder that included food justice information and resources, a one-page overview of each facilitation method taught at the workshop, and reflection guides. All contents of the binder can be found hyperlinked within Appendix A.

\section{Applied Research Methods}

This study uses a mixed-method phenomenological approach to better understand CPP participant experiences surrounding the central phenomenon of food justice pedagogy. According to Creswell and Poth (2018), phenomenological research is conducted to "reduce individual experiences with a phenomenon to a description of the universal essence." To collect data that assessed the impact of participant experiences, the authors conducted a reflective Post-Cohort Evaluation, a Post-Workshop Evaluation, and a Nine-Month Follow-up Evaluation of participants (Table 1).

The CPP coordinators developed each evaluation in partnership with the Extension Center for Family Development Applied Research and Evaluation team (ARE). The Nine-Month Follow-Up was developed by the authors of this article and the ARE team. Upon completing the UMN Human Research Determination form, we ascertained the project did not require IRB approval due to its focus on quality assurance.

Using inductive coding (Heit, 2000), the authors first independently identified themes in the evaluation reports from the two Qualtrics surveys and the field notes from the facilitated discussion. Then they came together to discuss emergent. Data was imported from the three evaluations into MindMup (version 2, 2017) software to represent the emerging codes visually. From there, the authors used the software to collaboratively sort and combine the codes to identify five emergent themes that helped make the learning experience positive and impactful.

\section{Table 1. Evaluation Overview}

\begin{tabular}{|c|c|c|c|}
\hline Indicators & Reflective Post-Cohort Evaluation & Reflective Post-Workshop Evaluation & Nine-Month Follow-Up Evaluation \\
\hline Purpose & $\begin{array}{l}\text { To better understand what } \\
\text { worked well, what could have } \\
\text { been improved, and how the } \\
\text { TTT experience impacted } \\
\text { cohort members' ability to do } \\
\text { food justice work. }\end{array}$ & $\begin{array}{l}\text { To better understand what } \\
\text { worked well, what could have } \\
\text { been improved, and how the } \\
\text { workshop impacted workshop } \\
\text { participants' ability to do food } \\
\text { justice work. }\end{array}$ & $\begin{array}{l}\text { To build a greater understanding } \\
\text { of the long-term impacts on } \\
\text { participants' level of connection to } \\
\text { other participants, knowledge and } \\
\text { skill retention, and actions taken } \\
\text { to advance food justice since } \\
\text { participating in the workshops. }\end{array}$ \\
\hline Date completed & February 2020 & $\begin{array}{l}\text { Within two weeks of completion } \\
\text { of the workshop }\end{array}$ & September 2020 \\
\hline Completion Rate & $85 \%$ (12 of 14 participants) & $78 \%$ (166 of 214 participants) & $42 \%$ (90 of 214 participants) \\
\hline Methodology & $\begin{array}{l}\text { Group discussion (virtual) } \\
\text { facilitated by the coordinators }\end{array}$ & Qualitative evaluation & Qualitative evaluation \\
\hline $\begin{array}{l}\text { Questions } \\
\text { (Appendix B) }\end{array}$ & Six open-ended questions & $\begin{array}{l}\text { Mix of Likert scale and open- } \\
\text { ended questions }\end{array}$ & $\begin{array}{l}\text { Mix of Likert scale and open- } \\
\text { ended questions }\end{array}$ \\
\hline $\begin{array}{l}\text { Evaluation } \\
\text { Software }\end{array}$ & Zoom and Google Documents & Qualtrics & Qualtrics \\
\hline
\end{tabular}




\section{Reflections on the Themes}

In this section, the authors offer reflections on the themes they identified from the evaluation data and use information from their personal experiences and field notes to help illustrate the impact of these themes, which include:

- Focusing on building relationships and forging connections across differences provides fertile ground to build together.

- Having community at the core of creation and implementation helps workshop participants feel comfortable to engage more fully. This may be especially true for BIPOC participants.

- Paying close attention to detail when curating the workshop environment helps to create a sense of belonging within the participants.

- Having participants learn by doing helps them feel more confident in utilizing the skills they built in the workshops.

- Anchoring facilitation skills in a topic of relevance to participants help make the skills more readily accessible.

\section{Theme \#1: Focusing on Building Relationships and Forging Connections Across Differences Provides Fertile Ground to Build Together.}

The evaluation results indicated that relationships were vital to participants' experience in the CPP program, which supports the centrality of relationships in food justice pedagogies in the current literature. The data from the Post-Cohort Evaluation suggested that the depth of relationships built in the T'TT cohort experience was impactful in building confidence and effectively facilitating workshops. As the authors reviewed the Post-Cohort Evaluation results and continued to receive informal feedback about the depth of relationships built at the workshops, they decided to include specific

"What is most exciting for me is that we came together from across the state... [we] built relationships and opportunities and connections statewide. This creates fertile ground to build together." (Post-Cohort Evaluation) questions in the Nine-Month Follow-Up Evaluation $(N=90)$, which showed positive value to participants' experiences:

- $92 \%$ agreed that relationships were important to their learning experience.

- $79 \%$ agreed they felt more connected to others working in food justice in their area.

- $70 \%$ agreed they have new relationships they otherwise would not have built.

- $65 \%$ agreed the relationships they built have helped them improve their work.

We believe these results appear particularly positive considering that COVID-19 forced most CPP participants to work virtually and henceforth limit contact with each other shortly after attending the workshops. For example, one Black community member from the Near North neighborhood in Minneapolis noted that "I feel loved and not alone as I have created a network of people to love and know me and I get to know and love them too!" (anonymous workshop participant, personal communication, August 20, 2020). We believe messages like this indicate the relationship development did not have a transient or false depth due to the impacts of COVID-19.

"I made some really great connections with other attendees! I work on food systems issues and was able to connect with people who work on transportation ... and partners who work on hunger. I also made personal connections talking about family and background with people of other races." (Post-workshop Evaluation Respondent)

\section{Theme \#2: Having Community at the Core of Creation and Implementation Helps Participants Feel Comfortable to Engage More Fully. This May be Especially True for BIPOC Participants.} This theme appears to be new to the food justice pedagogy literature but not new at all to justice movements. Going back to Freire's (2014) Pedagogy of the Oppressed, justice-based work is founded on the values of co-creating with those who are most impacted. The Post-Cohort Evaluation data suggested that centering community in all aspects of 
the project may have been particularly helpful for the BIPOC workshop participants. In aggregating the Nine-Month Follow-Up Evaluation data by racial identity, we found no noticeable difference in responses. We believe this is a positive sign, indicating that BIPOC participants were equally engaged and got as much out of the workshops as their White counterparts, which may not always be the case in mixed-race, justice-oriented training (Griffin, 2021).

\section{"Education must begin with the solution of the teacher-student contradiction, by reconciling the poles of the contradiction so that both are simultaneously teachers and students." (Freire, 2014, p. 52)}

Feedback indicated that one factor contributing to the strong workshop engagement was having facilitator teams that represented the diverse regional demographics of workshop participants. For example, at one workshop in rural Minnesota, there was a Colombian immigrant on the facilitation team, three Colombian immigrant participants, and at least 10 Latinx participants. While this workshop was held in an area of the state where the immigrant population may not always feel comfortable attending mixed-race educational offerings (Bushway, 2001), the facilitator reflected that "the workshop ... was a great success, especially for the Latino and Somali community. There were great conversations about how they felt taken into account."

Another example comes from a workshop hosted at a Native American-focused workforce development center. One of the facilitation team members and an author of this article had a close relationship with this center. As a result, the attendance of the workshop was almost 100\% Native American clients of this organization, which likely would not have occurred without the relationship with the facilitator. Additionally, there were two workshops held in the Near North, Minneapolis, and Rondo, St. Paul neighborhoods, both of which have a high Black population and experience the legacy impacts of racial covenants, redlining, structural racism, and a healthy mistrust of university researchers (Kaul et al., 2019; Scharff et al.,
"I thought it was pretty remarkable how quickly people opened up and were ready to share. That's not usual, so I've got to believe it's attributable to the facilitation making people feel comfortable." (Post-Workshop Evaluation Respondent)

2010). Despite this legacy, at least eight participants (of the 25) at each workshop were community members not associated with or paid to attend by an organization. We believe these people would not have participated if it wasn't for the facilitators' connections to the neighborhoods, but we cannot confirm this assumption in the evaluation data.

\section{Theme \#3: Paying Close Attention to Detail When Curating the Workshop Environment Helps to Create a Sense of Belonging Within the Participants.}

The importance of attention to detail emerged from the evaluation data. The trainers who led the TTT cohort training were skilled in the "Art of Hosting $(\mathrm{AOH})$," a leadership training that teaches facilitation skills, systems thinking, and innovation practices (Art of Hosting, n.d.). Part of the $\mathrm{AOH}$ training teaches leaders to create warm, inviting spaces. The TT'T cohort talked about how the thoughtfulness of the trainers in setting up the learning environment made them feel like they "belonged" and mentioned that "the small things really mattered."

As a result, the facilitation teams applied this same attention to detail in designing and implementing the workshops (as referenced in Practice \#5 of the CPP in Action section). The authors flagged 82 out of 243 responses in the Post-Workshop evaluation that pointed to the value of the facilitation teams paying close attention to detail and creating a welcoming environment for workshop participants to learn. For example, one workshop participant noted that "I honestly think that the facilitators anticipated the needs of participants when planning this workshop. Adequate breaks, good food, moving around the room, not very much lecturing, learning from others; all of these aspects made it a positive learning experience." There were even 12 comments specific to the importance of the binder of printed workshop 
materials provided to all participants. Ultimately, 96\% of respondents of the Post-Workshop evaluation $(N=166)$ agreed that the facilitators of their workshop did a great job of creating a welcoming environment for learning.

\section{Theme \#4: Having Participants Learn by Doing Helps Them Feel More Confident in Utilizing the Skills They Built in the Workshops.}

Another common theme identified in the data was the value of the "learner vs. participant mode" approach for participants (discussed further in Practice \#3 of the CPP in Action section). In the Post-Workshop Evaluation, one participant noted,

The environment created was incredibly conducive to all kinds of learners. There was an access point for each participant to engage with the materials, practice their skills and think deeply about how to apply what they learned. The training did an excellent job of both presenting the skills and tools and providing overarching discussion and practice in how those skills are applied in real time. They 'walked the walk' while 'talking the talk' which set an amazing example and allowed for deeper learning.

Many participants in the Post-Workshop Evaluation echoed this sentiment; the authors flagged 62 of 243 responses that highlighted how "learning by doing" helped participants understand the workshop concepts more fully. Nearly all (97\%) respondents $(N=166)$ noted improvement in their confidence in facilitating food justice conversations, with the degree of improvement divided between somewhat (41\%) and very much (56\%). Over 100 comments discussed how respondents were already utilizing their skills in their work just weeks after participating in the workshops. The knowledge and skills gained through the workshop seemed to be retained, as evidenced by several indices in the Nine-Month Follow-Up Evaluation $(N=90)$ :

- $86 \%$ of respondents somewhat or strongly agreed that the meetings or events they've led since the workshops are more engaging (participants look forward to attending and feel like their voices have been heard.)

- $77 \%$ of respondents somewhat or strongly agreed that they have supported others in planning and implementing more engaging meetings or events.

- $82 \%$ of respondents somewhat or strongly agreed that they bring a stronger lens of justice to their work (antiracism, dismpting systems, focusing on diversity)

- $69 \%$ of respondents somewhat or strongly agreed that they engage a more diverse audience in their work.

Again, we see these results as particularly positive, considering most workshop participants had to switch to working remotely and learn how to transfer their new skills to a virtual audience due to the COVID-19 pandemic.

\section{Theme \#5: Anchoring Facilitation Skills in a Topic of Relevance to Participants Helps Make the Skills More Readily Accessible.}

We believe this is another new contribution to the food justice pedagogy literature. To our knowledge, there has never been a workshop that taught facilitation skills rooted in the topic of food justice. Three comments in the Post-Workshop Evaluation spoke specifically to the power of rooting facilitation training in food justice, which was particularly important to the authors. Each of the three respondents noted that they had attended many facilitation trainings and social justice or racial equity trainings but that the merger of the two concepts made this workshop more impactful than any other they had previously attended. These comments, combined with the Nine-Month Follow-Up Evaluation results, which suggest a positive, sustained growth in the skills and knowledge of work-

"I like that these facilitation methods were grounded in a specific topic-previous facilitation trainings I have attended have all been about facilitation, and less on the subject matter. To me, this was definitely a more meaningful way to learn about facilitation while also meeting with like-minded folks doing similar work." (Post-Workshop Evaluation) 
shop participants, helped the authors understand the added value of teaching facilitation skills to groups of individuals who share a common passion, such as food justice.

- $100 \%$ of respondents somewhat or strongly agreed they had a greater understanding of the concept of food justice.

- $92 \%$ of respondents somewhat or strongly agreed they felt more equipped to engage in food justice work.

- $93 \%$ of respondents somewhat or strongly agreed they had a greater understanding of the different tools available to engage audiences in effective meetings.

- $92 \%$ of respondents somewhat or strongly agreed they felt more equipped to lead effective meetings.

\section{Putting It All Together}

We believe these five themes contributed to this learning experience's positive impact in equipping participants with relationships and skills to improve their food justice work. The actions participants outlined they have taken in the Post-Workshop Evaluation and Nine-Month Follow-Up Evaluation were numerous. Actions range from leading a group to develop their 2020 sustainable regional food system plan to more effective board meetings, staff meetings, and community gatherings to addressing Tribal food sovereignty issues to improving personal relationships.

\section{Areas of Growth}

Although the evaluation results and participant feedback were positive, some themes emerged for growth areas for the program from the Post-Workshop Evaluation. The most common critique of the workshops was that participants wanted more time for silent reflection (12 out of 243 comments). As a result of this feedback from early workshops, facilitation teams adapted their agendas for later workshops to include more time for silent reflection. Even with the adaptations, though, workshop participants still wanted more time for silent reflection. Workshop participants also wanted more topics that addressed facilitating through tension (6 of
243 comments). For instance, some suggested the addition of techniques for conflict resolution or how to address people who talk too much in meetings. Lastly, some participants (4 out of 243) noted confusion around workshop content. Some were surprised to find out that the workshops were so heavily focused on facilitation skill-building. We believe this points to the need for further clarity in the initial marketing and communications about the program's learning objectives.

In addition to the areas of growth identified in the evaluations, we reflected as a core team on steps that could be taken to improve future offerings. For example, we believe the program could go a step further in bringing stakeholders together to design food justice programs. The two-day workshops could include an additional third day of gathering where participants co-create action plans specific to their communities' needs, such as policy campaigns, cooperative farming models, urban land access, etc. Finally, we are currently designing the next round of CPP to take place virtually, which creates a whole new set of challenges in building trust and hosting difficult conversations without the enhanced personal connections best achieved through face-to-face interaction.

\section{Conclusion}

The Cultivating Powerful Participation program has proven to be a transformative model for Minnesota communities, Extension, and food system practitioners. It is novel in its marriage of food justice concepts with practical skill-building. The insights and examples shared here can help other food systems practitioners better understand the intersection of race and food and take collective action to dismantle oppressive systems that perpetuate food injustice. The practices and themes examined here demonstrate the need for practitioners to invest more deeply in facilitation, co-creation, and relationship development as vital skills for food justice work. By providing a detailed recounting of the design, outcomes, and stories from this experience, we hope others will be similarly transformed in their efforts to advance food justice in an authentic way that places community at the very center. 


\section{Acknowledgments}

We'd like to convey our deepest gratitude to the giants whose shoulders we stand upon, including the BIPOC leaders who have paved the way for justice-oriented work across the U.S. and the food systems practitioners who have been fighting for equitable systems change for decades. We also thank our Cultivating Powerful Participation cohort members with whom we built this program.

\section{References}

Aftandilian, D., \& Dart, L. (2013). Using garden-based service-learning to work toward food justice, better educate students, and strengthen campus-community ties. Journal of Community Engagement and Scholarship, 6(1). http://jces.ua.edu/using-garden-based-service-learning-to-work-toward-food-justice-better-educate-students-andstrengthen-campus-community-ties/

Art of Hosting. (n.d.). Home. https://www.artofhosting.org/

Brown, J., Connell, K., Firth, J., \& Hilton, T. (2020). The history of the land: A relational and place-based approach for teaching (more) radical food geographies. Human Geography, 13(3), 242-252. https://doi.org/10.1177/1942778620962024

Bushway, D. (2001). The vitality of Latino communities in rural Minnesota. Center for Rural Policy and Development. https://hacer-mn.org/staging/wp-content/uploads/2019/12/vitalitylatinocommunitiesruralminnesota.pdf

Butin, D. W. (2007). Justice-learning: Service-learning as justice-oriented education. Equity \& Excellence in Education, 40(2), 177-183. https://doi.org/10.1080/10665680701246492

Cadieux, K. V., \& Slocum, R. (2015). What does it mean to do food justice? Journal of Political Ecology, 22(1), 1-26. https://doi.org/10.2458/v22i1.21076

Community Alliance for Global Justice. (2013) Food justice project. Community Alliance for Global Justice. http://www.seattleglobaljustice.org/food-justice/

Community Alliance for Global Justice. (2013). Food justice project. https:/ / cagj.org/food-justice/

Compassionate Listening Project, The. (2013). Fundamentals of compassionate listening: Healing our world from the inside out. https://sherrymccreedy.weebly.com/uploads/1/3/8/9/13896697/compassionate listening-training-packetintro2.pdf

Creswell, J. W., \& Poth C.N. (2018). Qualitative inquiry and research design: Choosing among five approaches (4th Ed.). Sage.

Cserti, R. (2020, June 15). What is the train-the-trainer model? SessionLab. https://www.sessionlab.com/blog/train-the-trainer-model/

Freire, P. (2014). Pedagogy of the oppressed: 30th anniversary edition. Bloomsbury.

Gottlieb, R., \& Joshi, A. (2010). Food justice. MIT Press. https://doi.org/10.7551/mitpress/7826.001.0001

Griffin, S. R. (2021, February 6). Where “diversity training” goes wrong: 10 essential questions to ask. Medium. https://medium.com/@shaylargriffin/where-diversity-training-goes-wrong-10-essential-questions-to-ask$1217863 \mathrm{eab} 04$

Heeb, G. (2021, April 29). White farmers sue Biden administration, alleging racial discrimination in stimulus package. Forbes. https://www.forbes.com/sites/ginaheeb/2021/04/29/white-farmers-sue-biden-administration-allegingracial-discrimination-in-stimulus-package $/$ ?sh $=24 \mathrm{e} 0 \mathrm{dbca} 3754$

Heit, E. (2000). Properties of inductive reasoning. In J. E. Adler \& L. J. Rips (Eds.), Reasoning: Studies of human inference and its foundations (pp. 353-382). Cambridge University Press. https://doi.org/10.1017/cbo9780511814273.021

Holt-Giménez, E. (2015). Racism and capitalism: Dual challenges for the food movement. Journal of Agriculture, Food Systems, and Community Development, 5(2), 23-25. https://doi.org/10.5304/jafscd.2015.052.014

Holt-Giménez, E., \& Breeze, H. (2016). Dismantling racism in the food system. Food First. https://foodfirst.org/wp-content/uploads/2016/03/DR1Final.pdf

Hunjan, R., \& Pettit, J. (2011). Power: A practical guide for facilitating social change. Carnegie United Kingdom Trust. https://www.participatorymethods.org/sites/participatorymethods.org/files/Power-A-Practical-Guide-forFacilitating-Social-Change 0.pdf 
Institute for Agriculture and Trade Policy [IATP]. (2012). Draft principles of food justice. https://www.iatp.org/documents/draft-principles-of-food-justice

ICA International. (2015, November 21). ToP facilitation. ICA International. http://www.ica-international.org/top-facilitation/

Kaiser, M. L., Himmelheber, S., Miller, S., \& Hayward, R. A. (2015). Cultivators of change: Food justice in social work education. Social Work Education, 34(5), 544-557. https://doi.org/10.1080/02615479.2015.1063599

Kaul, G., Ehrenhalt, L., \& Walsh, J. (2019, February 26). With covenants, racism was written into Minneapolis housing. The scars are still visible. MinnPost. https://www.minnpost.com/metro/2019/02/with-covenants-racism-waswritten-into-minneapolis-housing-the-scars-are-still-visible/

Lee, R., \& Ahtone, T. (2020, March 30). Land-grab universities. High Country News. https://www.hcn.org/issues/52.4/indigenous-affairs-education-land-grab-universities

Levkoe, C. Z. (2006). Learning democracy through food justice movements. Agriculture and Human Values, 23, 89-98. https://doi.org/10.1007/s10460-005-5871-5

McCandless, K. (n.d.-b). Users experience fishbowl. Liberating Structures. https://www.liberatingstructures.com/18-users-experience-fishbowl/

MindMup 2. (2017). MindMup (Version 2) [Computer software]. https://www.mindmup.com/

Montenegro de Wit, M. (2020). What grows from a pandemic? Toward an abolitionist agroecology. The Journal of Peasant Studies, 48(1), 99-136. https://doi.org/10.1080/03066150.2020.1854741

Neiman, N., \& Schroedel, J. (2019). Plant justice: A case study in radical pedagogy and food justice in an alternative education setting. Creative Education, 10(8), 1937-1952. https://doi.org/10.4236/ce.2019.108140

Nittle, N. (2021, March 31). People of color are at greater risk of COVID-19. Systemic racism in the food system plays a role. Civil Eats. https://civileats.com/2020/05/05/people-of-color-are-at-greater-risk-of-covid-19-systemic-racismin-the-food-system-plays-a-role/

Okun, T. (1999). White supremacy culture. https://www.whitesupremacyculture.info/

Sbicca, J. (2018). Food justice now!: Deepening the roots of social struggle. University of Minnesota Press. https://doi.org/10.5749/i.ctv3dnnrt

Scharff, D. P., Mathews, K. J., Jackson, P., Hoffsuemmer, J., Martin, E., \& Edwards, D. (2010). More than Tuskegee: Understanding mistrust about research participation. Journal of Health Care for the Poor and Underserved, 21 (3), 879-897. https://doi.org/10.1353/hpu. 0.0323

University of Minnesota Extension [UMN]. (2020). Cultivating powerful participation: Food justice facilitation workshops. https://extension.umn.edu/courses-and-events/food-justice-workshops

Valley, W., Anderson, M., Blackstone, N. T., Sterling, E., Betley, E., Akabas, S., Koch, P., Dring, C., Burke, J., \& Spiller, K. (2020). Towards an equity competency model for sustainable food systems education programs. Elementa: Science of the Anthropocene, 8, Article 33. https://doi.org/10.1525/elementa.428

Zúñiga, X. (2003). Bridging differences through dialogue. About Campus, 7(6), 8-16. https://doi.org/10.1177/108648220300700603 


\section{Appendix A: Sample Agenda for Cultivating Powerful Participation Workshop}

All resources mentioned in this agenda can be found in this open-source Google Drive folder: https://drive.google.com/drive/u/1/folders/1t4PRD0Cmb30lewMjBWW1zwEME9wdopq7

\section{Day 1}

\begin{tabular}{|c|c|c|c|c|}
\hline Time & $\begin{array}{l}\text { Activity/ } \\
\text { Method }\end{array}$ & Description & Purpose & Lead \\
\hline $7: 30-8: 30$ & Set-Up & $\begin{array}{l}\text { Set up all tables, Hang all posters, Set up snacks } \\
\text { and beverages, Set up hospitality kit, etc. }\end{array}$ & $\begin{array}{l}\text { To make the space feel } \\
\text { warm and welcoming } \\
\text { when participants arrive }\end{array}$ & Everyone \\
\hline 8:30-9:15 & $\begin{array}{l}\text { Participant } \\
\text { Arrival }\end{array}$ & $\begin{array}{l}\text { Welcome participants as they arrive } \\
\text { Provide directions to get comfortable, have a } \\
\text { snack, find a spot at a table, network, and start } \\
\text { drawing their food story with the art supplies at } \\
\text { their tables. }\end{array}$ & $\begin{array}{l}\text { To help all participants } \\
\text { feel welcome as they } \\
\text { arrive and to start } \\
\text { getting people to think } \\
\text { outside of the box from } \\
\text { the beginning }\end{array}$ & Everyone \\
\hline $9: 15-9: 30$ & $\begin{array}{l}\text { Welcome / } \\
\text { Opening }\end{array}$ & $\begin{array}{l}\text { Overview of goals, objectives, and agenda } \\
\text { Emphasize the learner v participant mode and the } \\
\text { importance of rooting facilitation skills in the topic } \\
\text { of food justice } \\
\text { Provide a land acknowledgment }\end{array}$ & $\begin{array}{l}\text { To orient people to the } \\
\text { physical space, the } \\
\text { hopes we have for our } \\
\text { time together, and why } \\
\text { we want to talk about } \\
\text { facilitation and food } \\
\text { justice in the same } \\
\text { gathering }\end{array}$ & $\begin{array}{l}\text { Facilitator \#1 } \\
\text { and \#2 }\end{array}$ \\
\hline $9: 30-10: 00$ & $\begin{array}{l}\text { Opening } \\
\text { Activity }\end{array}$ & $\begin{array}{l}\text { Opening Circle: } \\
\text { We'll go around the circle, share name, pronoun, } \\
\text { organization (if applicable), \& one thing you want } \\
\text { us to know about your relationship to food justice } \\
\text { in three sentences or less }\end{array}$ & $\begin{array}{l}\text { Get to know people and } \\
\text { understand what drove } \\
\text { them to attend }\end{array}$ & Facilitator \#3 \\
\hline 10:00-10:20 & $\begin{array}{l}\text { Shared } \\
\text { Agreements }\end{array}$ & Introduce and co-create Shared Agreements & $\begin{array}{l}\text { Collaborative effort to } \\
\text { co-create the type of } \\
\text { space they want to } \\
\text { create together. }\end{array}$ & Facilitator \#4 \\
\hline $10: 20-10: 35$ & Break & & & \\
\hline $10: 35-11: 55$ & $\begin{array}{l}\text { World Cafe + } \\
\text { ORID }\end{array}$ & $\begin{array}{l}\text { Introduction to World Cafe (learner mode) } \\
\text { Activity: (participant Mode) } \\
\text { - Round 1: What sticks out to you about these } \\
\text { food injustice facts? (Refer to Facts Sheet) } \\
\text { - Round 2: What would a just food system feel } \\
\text { like to you? } \\
\text { - Round 3: What does facilitation have to do with } \\
\text { creating a just food system? } \\
\text { - Round 4: How do you plan to use these skills to } \\
\text { fight for food justice in your work? } \\
\text { Harvest Conversation: } \\
\text { - What stuck out to you as powerful in this } \\
\text { conversation? }\end{array}$ & $\begin{array}{l}\text { To get people grounded } \\
\text { in the idea of justice and } \\
\text { the connection to } \\
\text { facilitation. }\end{array}$ & Facilitator \#1 \\
\hline
\end{tabular}


Day 1, continued

\begin{tabular}{|c|c|c|c|c|}
\hline Time & $\begin{array}{l}\text { Activity/ } \\
\text { Method }\end{array}$ & Description & Purpose & Lead \\
\hline $11: 55-12: 10$ & $\begin{array}{l}\text { World Cafe } \\
\text { Debrief }\end{array}$ & $\begin{array}{l}\text { Brief reminder of World Cafe basics (back to } \\
\text { learner mode) } \\
\text { Debrief Conversation (popcorn): } \\
\text { - What questions do you have about the method? } \\
\text { - What did you think of this method? } \\
\text { Silent Reflection in Journal on Method }\end{array}$ & $\begin{array}{l}\text { Give participants a } \\
\text { chance to reflect, think } \\
\text { about application, and } \\
\text { take notes. }\end{array}$ & Facilitator \#1 \\
\hline $12: 10-1: 00$ & Lunch & & & \\
\hline $1: 00-1: 30$ & ORID & $\begin{array}{l}\text { Overview of ORID and how it was snuck into } \\
\text { World Cafe experience (learner mode) } \\
\text { Activity: (participant mode) } \\
\text { Create a list of } 4 \text { questions based on the follow- } \\
\text { ing purpose: “Imagine you were a part of a team } \\
\text { that hosted a community gathering to help } \\
\text { understand their needs related to food justice. } \\
\text { You come back together with the hosting team to } \\
\text { talk about next steps. What questions could you } \\
\text { ask using the ORID method?" } \\
\text { Harvest Conversation: } \\
\text { - How did it feel to craft your questions in this } \\
\text { way? (pair share) } \\
\text { - How could you use this method in your work? } \\
\text { (small group) } \\
\text { - What do you think about this method? (large } \\
\text { group) } \\
\text { We actually just practiced another facilitation } \\
\text { method called 1-2-4-All! }\end{array}$ & $\begin{array}{l}\text { To explain that we also } \\
\text { used ORID during our } \\
\text { World Cafe and how it } \\
\text { can be used as a tool to } \\
\text { help make decisions. }\end{array}$ & Facilitator \#2 \\
\hline $1: 40-2: 35$ & $\begin{array}{l}\text { Reflective } \\
\text { Listening }\end{array}$ & $\begin{array}{l}\text { Introduction to Reflective Listening (learner } \\
\text { mode) } \\
\text { Activity: (participant mode) } \\
\text { - Break into groups of } 4>1 \text { Speaks, } 3 \text { Listen } \\
>1 \text { listens for facts, } 1 \text { listens for emotions, } \\
1 \text { listens for values > } 6 \text { min talk / } 4 \text { min } \\
\text { reflection (1ish min each) > each person has } \\
\text { a chance to present and listen in different } \\
\text { ways } \\
\text { - Question: How has courage shown up in your } \\
\text { work in the food system / food justice? } \\
\text { Harvest Conversation: } \\
\text { - How did it feel to share your story with others? } \\
\text { - How did it feel to listen for facts? } \\
\text { - How did it feel to listen for emotions? } \\
\text { - How did it feel to listen for values? }\end{array}$ & $\begin{array}{l}\text { To have people share } \\
\text { through storytelling and } \\
\text { learn to listen with their } \\
\text { whole selves as they move } \\
\text { through the rest of the } \\
\text { workshop. }\end{array}$ & Facilitator \#3 \\
\hline
\end{tabular}


Day 1, continued

\begin{tabular}{|c|c|c|c|c|}
\hline Time & $\begin{array}{l}\text { Activity/ } \\
\text { Method }\end{array}$ & Description & Purpose & Lead \\
\hline $2: 35-2: 50$ & $\begin{array}{l}\text { Reflective } \\
\text { Listening } \\
\text { Debrief }\end{array}$ & $\begin{array}{l}\text { Brief reminder of Reflective Listening basics } \\
\text { (back to learner mode) } \\
\text { Debrief Conversation (popcorn): } \\
\text { - What questions do you have about the } \\
\text { method? } \\
\text { - What did you think of this method? } \\
\text { Silent Reflection in Journal on Method }\end{array}$ & $\begin{array}{l}\text { Give participants a } \\
\text { chance to reflect, think } \\
\text { about application, and } \\
\text { take notes. }\end{array}$ & $\begin{array}{l}\text { Facilitator } \\
\text { \#3 }\end{array}$ \\
\hline 2:50-3:00 & $\begin{array}{l}\text { Movement } \\
\text { Break } \\
\text { (Entourage) }\end{array}$ & Provide instructions and do it with enthusiasm & $\begin{array}{l}\text { To help wake people up } \\
\text { and get them out of their } \\
\text { heads. }\end{array}$ & $\begin{array}{l}\text { Facilitator } \\
\text { \#1 }\end{array}$ \\
\hline 3:00-4:10 & Round Robin & $\begin{array}{l}\text { Introduce Round Robin as a Method (learner } \\
\text { mode) } \\
\text { Activity: (participant mode) } \\
\text { - } 20 \text { min / table, choose } 3 \text { of } 4 \text { tables } \\
\text { - Table \#1: Visioning \& Current Reality } \\
\text { - Table \#2: Fishbowl } \\
\text { - Table \#3: Basics to Convening } \\
\text { - Table \#4: Emergence, Divergence, Convergence } \\
\text { Harvest: } \\
\text { - What ah-ha's are sticking with you after this } \\
\text { - whirlwind of learning? } \\
\text { - What questions do you still have? }\end{array}$ & $\begin{array}{l}\text { To provide a variety of } \\
\text { tools and ideas to help } \\
\text { them understand how to } \\
\text { facilitate food justice } \\
\text { conversations. }\end{array}$ & All \\
\hline 4:10-4:25 & $\begin{array}{l}\text { Round Robin } \\
\text { Debrief }\end{array}$ & $\begin{array}{l}\text { Brief reminder of Reflective Listening basics } \\
\text { (back to learner mode) } \\
\text { Debrief Conversation (popcorn): } \\
\text { - What questions do you have about the } \\
\text { method? } \\
\text { - What did you think of this method? } \\
\text { Silent Reflection in Journal on Method }\end{array}$ & $\begin{array}{l}\text { Give participants a } \\
\text { chance to reflect, think } \\
\text { about application, and } \\
\text { take notes. }\end{array}$ & $\begin{array}{l}\text { Facilitator } \\
\text { \#1 }\end{array}$ \\
\hline $4: 25-4: 45$ & Closing & $\begin{array}{l}\text { Overview of what was learned } \\
\text { What to expect tomorrow } \\
\text { Circle Activity: } \\
\text { - Collective breathing } \\
\text { - Say one word that describes how you're } \\
\text { feeling right now. }\end{array}$ & $\begin{array}{l}\text { Provide space to } \\
\text { remember, get grounded, } \\
\text { and release any tension, } \\
\text { fears, or overwhelm. }\end{array}$ & $\begin{array}{l}\text { Facilitator } \\
\# 2\end{array}$ \\
\hline
\end{tabular}


Day 2

\begin{tabular}{|c|c|c|c|c|}
\hline Time & $\begin{array}{l}\text { Activity/ } \\
\text { Method }\end{array}$ & Description & Purpose & Lead \\
\hline $7: 30-8: 30$ & Set-Up & $\begin{array}{l}\text { Set up all tables, Hang all posters, Set up snacks } \\
\text { and beverages, Set up hospitality kit, etc. }\end{array}$ & Same as Day 1 & Everyone \\
\hline $8: 30-9: 15$ & $\begin{array}{l}\text { Participant } \\
\text { Arrival }\end{array}$ & Welcome participants as they arrive & Same as Day 1 & Everyone \\
\hline $9: 15-9: 35$ & Welcome & Same as Day 1 (no land acknowledgement) & Same as Day 1 & $\begin{array}{l}\text { Facilitator } \\
\# 1\end{array}$ \\
\hline $9: 35-10: 05$ & $\begin{array}{l}\text { Web of } \\
\text { Connected- } \\
\text { ness }\end{array}$ & $\begin{array}{l}\text { Introduce activity } \\
\text { - Have group gather in circle } \\
\text { - Hold piece of yarn and share response to one } \\
\text { or both questions (What is still lingering for } \\
\text { you from yesterday? And/or What are you } \\
\text { hopeful for today?) } \\
\text { - Call someone's name and throw them the } \\
\text { - } \text { yarn. } \\
\text { continues until everyone has responded. } \\
\text { Implement activity } \\
\text { Debrief the activity } \\
\text { - Reminder - we are not alone, we are all in this } \\
\text { together. Together we are stronger! } \\
\text { - Ask what are others' favorite icebreakers }\end{array}$ & $\begin{array}{l}\text { To help participants see } \\
\text { how interconnected our } \\
\text { work is and to have a fun } \\
\text { way to start the day }\end{array}$ & $\begin{array}{l}\text { Facilitator } \\
\text { \#2 }\end{array}$ \\
\hline 10:05-10:15 & Break & & & \\
\hline $10: 15-11: 35$ & $\begin{array}{l}\text { Peer } \\
\text { Consultation }\end{array}$ & $\begin{array}{l}\text { Introduce Peer Consultation (learner mode) } \\
\text { Activity (participant mode) } \\
\text { - Silent reflection on project you want advice on } \\
\text { - Break into groups of } 4 \\
\text { - Each person gets } 15 \text { minutes to share about } \\
\text { their project, what they want help with, and } \\
\text { the three others offer consultation. } \\
\text { (Emphasize leaving as much time as possible } \\
\text { for the consultation piece) }\end{array}$ & $\begin{array}{l}\text { To help participants get } \\
\text { advice on their projects } \\
\text { and learn how to work } \\
\text { on projects in } \\
\text { collaborative/group } \\
\text { oriented way }\end{array}$ & $\begin{array}{l}\text { Facilitator } \\
\text { \#3 }\end{array}$ \\
\hline $11: 35-12: 00$ & $\begin{array}{l}\text { Peer } \\
\text { Consultation } \\
\text { Debrief }\end{array}$ & $\begin{array}{l}\text { Brief reminder of Peer Consultation basics (back to } \\
\text { learner mode) } \\
\text { Debrief Conversation (popcorn): } \\
\text { - What questions do you have about the } \\
\text { method? } \\
\text { - What did you think of this method? } \\
\text { Silent Reflection in Journal on Method }\end{array}$ & $\begin{array}{l}\text { To help participants } \\
\text { understand how to apply } \\
\text { the method to their work }\end{array}$ & $\begin{array}{l}\text { Facilitator } \\
\text { \#3 }\end{array}$ \\
\hline
\end{tabular}


Day 2, continued

\begin{tabular}{|c|c|c|c|c|}
\hline Time & $\begin{array}{l}\text { Activity/ } \\
\text { Method }\end{array}$ & Description & Purpose & Lead \\
\hline $12: 00-12: 45$ & Lunch & & & \\
\hline $12: 45-1: 55$ & $\begin{array}{l}\text { Open Space } \\
\text { Technology }\end{array}$ & $\begin{array}{l}\text { Introduce Activity (learner mode) } \\
\text { Activity (participant mode) } \\
\text { - Our Question: What do we need to dig deeper } \\
\text { on? Pressing food justice issues? Teaching } \\
\text { methods? Questions about facilitation? } \\
\text { - You place a topic you want to discuss based } \\
\text { on this topic. When you place your topic, you } \\
\text { announce it to the group and take a notes } \\
\text { sheet. You will be the lead of that topic in the } \\
\text { Round chosen during the Market Place } \\
\text { - Market Place }>\text { Round } 1>\text { Round } 2>1 \text { chime } \\
\text { for } 2 \text { minutes left }>2 \text { chimes for time to } \\
\text { change to round } 2 \text { if you want }\end{array}$ & $\begin{array}{l}\text { Offering a space to go } \\
\text { deeper into food justice } \\
\text { in a way that is self- } \\
\text { organized and self- } \\
\text { directed. If they feel like } \\
\text { this training is lacking } \\
\text { anything, now is there } \\
\text { chance to get the most } \\
\text { out of it. }\end{array}$ & $\begin{array}{l}\text { Facilitators } \\
\# 1 \text { \& \#2 }\end{array}$ \\
\hline $1: 55-2: 10$ & $\begin{array}{l}\text { Open Space } \\
\text { Technology } \\
\text { Debrief }\end{array}$ & $\begin{array}{l}\text { Brief reminder of Peer Consultation basics (back to } \\
\text { learner mode) } \\
\text { Debrief Conversation (popcorn): } \\
\text { - What questions do you have about the } \\
\text { method? } \\
\text { - What did you think of this method? } \\
\text { Silent Reflection in Journal on Method }\end{array}$ & $\begin{array}{l}\text { To help participants } \\
\text { understand how to apply } \\
\text { the method to their work }\end{array}$ & $\begin{array}{l}\text { Facilitators } \\
\# 1 \& \# 2\end{array}$ \\
\hline $2: 10-2: 25$ & Break & & & \\
\hline $2: 25-3: 45$ & Teach Back & $\begin{array}{l}\text { Overview of Teach Back (learner mode) } \\
\text { Activity (participant mode) } \\
\text { Get in Groups of } 4>\text { Review a Method from Binder } \\
\text { Silently > Come up with Application for Your Work, } \\
\text { including questions and instructions > Teach the } \\
\text { method back your group members (each member } \\
\text { teaching a different method to each other) }\end{array}$ & $\begin{array}{l}\text { To help participants } \\
\text { learn practice facilitation } \\
\text { and think about how to } \\
\text { apply to their work. }\end{array}$ & $\begin{array}{l}\text { Facilitator } \\
\# 3\end{array}$ \\
\hline $3: 45-4: 00$ & Closing Circle & $\begin{array}{l}\text { Introduce activity, thank participants, express } \\
\text { gratitude for the experience. } \\
\text { Activity: } \\
\text { - Get participants into a circle } \\
\text { - Have participants share one word or a story } \\
\text { that was most valuable to them about this } \\
\text { experience }\end{array}$ & $\begin{array}{l}\text { To have people dig } \\
\text { deeper into what they } \\
\text { got out of today's } \\
\text { session using a } \\
\text { facilitation method. }\end{array}$ & $\begin{array}{l}\text { Facilitator } \\
\# 1\end{array}$ \\
\hline
\end{tabular}




\section{Appendix B: Evaluation Questions}

\section{Cultivating Powerful Participation}

Facilitation Cohort Debrief Discussion Questions

1. What are you most proud of from the Food Justice Facilitation Workshop experience?

2. What stands out the most to you from the evaluation results of the workshops? [Evaluation results were shared with participants through Google documents before this discussion.]

3. What helped you kick butt in facilitating the workshop? ["Kicking butt" refers to a part of a step-by-step guide they all used to plan their workshops]

4. What changes have you noticed within yourself since our time together?

5. Have you noticed any changes or ripple effects within the community or organization since the workshop?

6. What are the next steps that should be pursued in this work?

- How are you planning on using these skills moving forward?

○ Would you be interested in facilitating another workshop in the future?

\section{Cultivating Powerful Participation}

Post-Workshop Evaluation Questions

\section{Page 1:}

Thank you for attending a Cultivating Powerful Participation: Food Justice Facilitation Workshop! We are excited to hear what you thought of your event. All information you share will be anonymous and confidential.

1. Which workshop did you attend? (multiple choice with options for each location)

2. How much did your confidence in facilitating conversations about food justice work change by attending this workshop? (multiple choice: Not at all, Somewhat, Very much so)

3. How did the facilitators of this workshop do ... (Likert scale: Needs Improvement, OK, Great!) $\circ \quad .$. In creating a welcoming environment for learning?

- ... In conveying methods, practices, and concepts in meaningful ways?

$\circ \quad .$. In allowing all voices to be heard?

4. Based on your answers to the previous question, is there any advice you'd like to give the facilitators? (open-ended)

\section{Page 2:}

1. How was your learning experience? What went well? (open-ended)

2. How do you plan to use the methods, practices, and concepts you learned? (open-ended)

3. What, specifically, could have been improved about your learning experience? (open-ended)

4. What else should we know about your experience? (open-ended)

Click here to enter your name [HERE] for a chance to win your choice of the following books. (Emergent Strategy; Farming While Black; The Sioux Chef's Indigenous Kitchen) 


\section{Appendix C: Questions from Nine-Month Follow-Up Evaluation}

\section{Cultivating Powerful Participation Nine-Month Follow-Up Evaluation Questions}

\section{Page 1:}

Thank you for attending an in-person Cultivating Powerful Participation: Food Justice Facilitation Workshop in late 2019 or early 2020 ! Now that you've had time to sit with the information you learned, we'd love to hear how you've used what you learned in your life and work. All information you share will be anonymous. If you have any questions about the survey you can email Jamie Bain (jbain@umn.edu).

1. Which workshop did you attend? (multiple choice with options for each location)

\section{Subtitle: Demographics}

2. What area of the state best represents the place where you work? (multiple choice with options for different regions of the state, statewide, and other)

3. How do you identify racially? (open-ended)

\section{Page 2:}

\section{Subtitle: Connections}

4. Rate your level of agreement or disagreement for the following statements related to the CONNECTIONS you built as a result of your participation in the Cultivating Powerful Participation: Food Justice Facilitation workshop. (Likert scale: Strongly agree, Agree, Somewhat agree, Neither agree or disagree, Somewhat disagree, Disagree, Strongly disagree)

- The relationships I built at the workshop were important to my learning experience

- I feel more connected to others working on food justice in my area

- I have new relationships I otherwise wouldn't have built

○ The relationships I built at the workshop have helped me improve my work

5. If applicable, tell us about any meaningful connections you've had with people you met at the Cultivating Powerful Participation: Food Justice Facilitation Workshop. We are specifically interested if these connections were across boundaries (e.g., sector, geography, race). (open-ended)

\section{Page 3:}

\section{Subtitle: Knowledge \& Skills}

6. Rate your level of agreement or disagreement for the following statements related to the the KNOWLEDGE \& SKILLS you gained as a result of your participation in the Cultivating Powerful Participation: Food Justice Facilitation workshop. (Likert scale: Strongly agree, Agree, Somewhat agree, Neither agree or disagree, Somewhat disagree, Disagree, Strongly disagree)

- I have a greater understanding of the concept of food justice

- I feel more equipped to engage in food justice work

- I have a greater understanding of the different tools available to engage audiences in effective meetings

- I feel more equipped to lead effective meetings 
7. If applicable, how have you shared your knowledge and skills you learned from the Cultivating Powerful Participation: Food Justice Facilitation Workshop with others? (open-ended)

\section{Page 4:}

\section{Subtitle: Actions}

8. Rate your level of agreement or disagreement to the following statements regarding the ACTIONS you've taken as a result of your participation in the Cultivating Powerful Participation: Food Justice Facilitation Workshop. (Likert scale: Strongly agree, Agree, Somewhat agree, Neither agree or disagree, Somewhat disagree, Disagree, Strongly disagree)

- The meetings or events l've led since the workshop are more engaging (i.e., participants look forward to attending and feel like their voices have been heard)

- I have supported others in planning and implementing more engaging meetings or events

- I bring a stronger lens of justice to my work (e.g., anti-racism, disrupting systems, focusing on diversity, etc.)

- I engage a more diverse audience in my work

9. Please share any stories that help to illustrate how you have shifted or not shifted the way you work based on your participation in the Cultivating Powerful Participation: Food Justice Facilitation Workshop. (openended)

\section{Page 5:}

\section{Subtitle: Next Steps}

10. How much did COVID impact your ability to use your connections, skill \& knowledge gain, and/or actions you planned to take following your attendance of the Cultivating Powerful Participation: Food Justice Facilitation Workshop? (multiple choice: Very Much, Somewhat, A little, Not at all, Other, with open-ended box)

11. Please share anything else you'd like us to know about your experience with the Cultivating Powerful Participation: Food Justice Facilitation Workshop. (open-ended)

Click here to enter your name [HERE] for a chance to win your choice of the following books. (Emergent Strategy; Farming While Black; In the Shadow of Green Man; Braiding Sweetgrass) 